\title{
Spot urinary protein/osmolality ratio as a predictor for proteinuria of nephrotic range
}

\author{
Salma Jahan ${ }^{1}$, Md. Saiful Islam ${ }^{2}$ and Md. Moazzam Hossain ${ }^{1}$ \\ ${ }^{1}$ Department of Pediatrics Nephrology; ${ }^{2}$ Department of Urology, \\ Bangabandhu Sheikh Mujib Medical University, Shahbag, Dhaka, Bangladesh.
}

\begin{abstract}
A prospective study was carried out on 50 patients (age 1-15 years) with nephrotic range of proteinuria to determine the correlation of 24-hour urinary total protein with spot urinary protein/creatinine ratio and urinary protein/osmolality ratio. Another 50 patients having no proteinuria grouped as control. Twenty-four hours urine and spot urine were collected from each child and were analyzed for total volume, total protein, creatinine and osmolality level. The average 24-hour urinary total proteins in nephritic patient were $2148.6 \pm 808.7 \mathrm{mg}$ and the spot urinary protein/creatinine and spot urinary protein/osmolality were $3.2332 \pm 0.4293 \mathrm{mg} / \mathrm{mg}$ and $3.2418 \pm 0.4393 \mathrm{mg} / \mathrm{mOsm}$ respectively. There was a strong positive correlation of the 24-hour urinary total protein with spot urinary protein/creatinine and protein/osmolality ratios $(\mathrm{r}=0.9846$ and $0.9870, \mathrm{p}=<0.001)$. But in control group, these ratios did not show any correlation with 24-hour urinary total protein. These results suggest that in pediatric patients with nephrotic range of proteinuria, the spot urinary protein/osmolality ratio can predict the 24 -hour urinary total protein excretion like that of spot urinary protein/creatinine ratios.
\end{abstract}

\section{Introduction}

The examination of urine for proteinuria is significant in recognizing renal diseases. In addition, quantitative protein measurements have had great utility in evaluation for the diagnosis, prognosis, and effect of treatment. The routine urinalysis has a poor specificity-sensitivity profile for determining either the presence or absence of abnormal proteinuria or quantitative change in protein excretion ${ }^{1}$.

The 24-hour urine protein excretion test is regarded as the standard for quantitative protein analysis and commonly used to evaluate patients with known renal disease. However, this quantitation requires a 24-hour urine collection, which is usually difficult, particularly in an out-patient setting or when patients are undergoing other laboratory testing. It is known that the semi-quantitative urine protein analysis or even quantitative random protein concentrations correlate poorly with the quantitative 24-hour urine protein measurements ${ }^{2}$. However, the ratio of urinary protein to creatinine levels in a single voided urine sample has been reported as a simple index for the 24-hour urine protein level in some studies $3,4,5,6$.

Although absolute 24-hour urine creatinine levels usually do not depend on the severity of glomerular injury. Fluctuating pattern in urinary creatinine excretion is observed throughout the day, depending on the degree of glomerular injury. Thus, pattern of excretion of creatinine and protein and the urinary protein/creatinine ratio may vary according to the severity and type of glomerular diseases. However, it is shown that protein/ creatinine ratio in timed or un-timed random urine samples accurately reflect 24 -hour urinary protein excretion ${ }^{7}$.

For the measurement of proteinuria in children protein/creatinine ratio is more accurate than protein/osmolality ratio, but in adult it is equally accurate ${ }^{8}$. Morning urinary protein/osmolality ratio is a simple and potentially useful test for 24-hour urinary protein excretion, and can be used safely for the assessment of the degree of proteinuria in children $^{9}$. The quantitative urinary protein/ osmolality ratio is better than a qualitative 
urinalysis and urinary protein/creatinine ratio for detecting or assessing abnormal proteinuria and allows for a reasonable prediction of 24-hour protein level $^{10}$.

In this study, the correlations of 24-hour urinary protein with spot urinary protein/creatinine and protein/osmolality ratios were compared in a particular age group. The urinary protein/ osmolality ratio is an easy process in the measurement of the proteinuria over 24-hour urinary sample collection. Like protein/creatinine ratio, its result dose not varies with degree of glomerular injury. It is faster, less time consuming, cost effective and can be done from routine urine analysis.

\section{Materials and Methods}

This hospital based cross sectional study was carried out from July 2004 to June 2005. A total of 100 patients (age range 1-15 years) attending the Department of Pediatric Nephrology were included in this study. Fifty of them with nephrotic range of proteinuria were grouped as Group I and 50 patients having no proteinuria grouped as Group II. Samples were collected randomly as per inclusion and exclusion criteria. The inclusion criteria for Group I were nephrotic range of proteinuria detected by bed side heat coagulation test of urine for protein were positive ( +3 or more) and that for Group II were those patients whose bedside heat coagulation test of urine for protein were negative (no precipitation). The exclusion criterion was impaired renal function.

Patients were instructed to collect their 24-hour urine sample at home or in hospital in a clean container with $1 \mathrm{ml}$ toluene blue at room temperature and were taken to the laboratory where they again voided for spot sample which was collected in a separate container. Both the 24-hour and spot samples were then analyzed for total protein, creatinine, and osmolality levels. The 24hour urinary total protein and the spot urinary protein were measured by microflow cell photometer and the results were in $\mathrm{mg} / \mathrm{dl}$, which were then multiplied by total volume of 24-hour urine for urinary total protein. For the measurement of urinary creatinine, $100 \mu \mathrm{l}$ of 10 times diluted urine sample was taken along with $1,000 \mu \mathrm{L}$ of reagent (picric acid $14 \mathrm{mM}, \mathrm{NaOH} 0.18 \mathrm{mM}, \mathrm{Na}$ tetraborate $10 \mathrm{mM}$, surfactant) and readings were taken in microflow cell photometer. The result was presented in $\mathrm{mg} / \mathrm{dl}^{11}$. The osmolality was measured by osmometer (OSMOMETER 800cl, Slamed) which is a compact microprocessor controlled analyzer for easy and precise osmolality tests. The measuring principle is the cryometric method and the measuring range covers 0 to $2,000 \mathrm{mOsm} / 1 \mathrm{~kg}$ $\mathrm{H}_{2} \mathrm{O}$. The nephrotic range proteinuria means proteinuria $\geq 1 \mathrm{mg} / \mathrm{m}^{2} / 24$-hour whereas normal range proteinuria means proteinuria $\leq 4 \mathrm{mg} / \mathrm{m}^{2} / 24$ hour. The normal urinary protein/osmolality ratio is 0.12 or less. The nephrotic range protein/osmolality ratio is $>2.5$.

Statistical analysis: The amount of proteinuria was correlated with protein/creatinine and protein/ osmolality ratio. All the values were then analyzed for statistical significance. The correlation coefficients test or r-test was estimated using-

$$
\mathrm{r}=\Sigma\left(\mathrm{x}-\mathrm{x}^{-}\right)\left(\mathrm{y}-\mathrm{y}^{-}\right) \div \sqrt{ } \Sigma\left(\mathrm{x}-\mathrm{x}^{-}\right)^{2}\left(\mathrm{y}-\mathrm{y}^{-}\right)^{2}
$$

The data were analyzed for test of significance with $\chi^{2}$-test, t-test and r-test, using SPSS-WIN 12.0 versions. Probability (p) value $<0.05$ was considered as significant.

\section{Results}

Group I comprised of 28 males and 22 females with mean \pm SD age of $6.29 \pm 3.48$ years. The range of body surface area was $0.472 \mathrm{~m}^{2}-1.3 \mathrm{~m}^{2}$ in Group I and $0.5 \mathrm{~m}^{2}-1.1 \mathrm{~m}^{2}$ in Group II. The mean value of the 24-hour urinary total protein was 2,148.6 \pm $808.75 \mathrm{mg} / 24$-hour (range 1,150 - 4,686 mg/24 hour) and the spot urinary protein/creatinine and protein/osmolality ratios were $3.2332 \pm 0.4293$ $\mathrm{mg} / \mathrm{mg}$ and $3.2418 \pm 0.4349 \mathrm{mg} / \mathrm{mOsm}$ respecttively (Table I). There was a strong correlation of the 24-hour urinary total protein with the spot urinary protein/creatinine $(r=0.9846, \quad \mathrm{p}=<0.001)$ and protein/osmolality $(r=0.9870, \quad \mathrm{p}=<0.001)$ ratios.

In Group II, there were 30 male and 20 female with mean \pm SD age of $5.68 \pm 2.96$ years. The mean 24 hour urinary total protein was $83.62 \pm 31.33 \mathrm{mg} / 24$ hour (range $42-167 \mathrm{mg} / 24$ hour) and the spot urinary protein/creatinine and protein/osmolality ratios were $0.3051 \pm 0.0541 \mathrm{mg} / \mathrm{mg}$ and $0.3181 \pm$ $0.0493 \mathrm{mg} / \mathrm{mOsm}$ respectively. There was no correlation with the spot urinary protein/creatinine $\left(r=0.1035, \quad \mathrm{p}=>0.05^{\mathrm{ns}}\right)$ and protein/osmolality $\left(r=0.0699, \mathrm{p}=>0.05^{\mathrm{ns}}\right)$ ratios. 
Table I: Correlation of 24-hour urinary total protein with the spot urinary protein-createnine ratios (Uprot/Ucr) and protein/osmolality ratio (Uprot/Uosm)

\begin{tabular}{lrccc}
\hline Groups & $\begin{array}{c}\text { 24-hour urinary total } \\
\text { protein }(\mathrm{mg} / 24 \text { hour })\end{array}$ & $\begin{array}{c}\text { Uprot-Ucr ratio } \\
(\mathrm{mg} / \mathrm{mg})\end{array}$ & $\mathrm{p}$ & $\begin{array}{c}\text { Uprot-Uosml ratio } \\
(\mathrm{mg} / \mathrm{mOsm})\end{array}$ \\
\hline Group I & $2148.0 \pm 808.7$ & $3.2332 \pm 0.4293$ & $<0.001$ & $3.2418 \pm 0.4393$ \\
Group II & $83.6 \pm 31.3$ & $0.3051 \pm 0.0541$ & $>0.05$ & $0.3181 \pm 0.0493$ \\
\hline
\end{tabular}

\section{Discussion}

Proteinuria occurs commonly in children and adolescent and seems not to imply serious renal disease when present in an isolated or intermittent pattern or in relationship to a change of posture ${ }^{12}$,

13. The amount of protein excreted in the urine has diagnostic and prognostic importance and is used to asses the effectiveness of therapy ${ }^{14,15,16}$.

Several methods are used to detect urinary protein such as dipstick technology or sulfosalicylic acid for semi-quantitative measurements. The most common method for quantitating urinary protein relies on 24-hour urine collection. Obtaining accurately timed collection can be cumbersome and time consuming in a child and adult ${ }^{17}$, and more difficult in an young infant. So to find out a simple and effective method that can be substituted for the determination of protein excretion in 24-hour urine collection may be a reasonable goal. Commonly used quantitative random protein determination is a simple method, but correlate poorly with the quantitative 24-hour urine protein measurements. The reason for this poor correlation include: dehydration-hydration, which affects the concentration of urinary protein because the amount of protein excreted is independent of the volume of urine. It was shown that there is variability in protein excretion with altered glomerular filtration rate ${ }^{18}$.

The 24-hour urinary total protein levels in this study showed significant difference among the two groups. The findings of this study had a similarity with the findings of other studies. Houser (1984) and Kim et al., (2001) showed that the daily protein excretion in their adult volunteers having normal range of proteinuria but in patients sample they had higher range of proteinuria then our study as they had dealt with adult group of patients ${ }^{6,9}$.

Morgenstern et al., (2003) showed ratios in relation to age but their overall findings were not similar to this study because of wide range of age. They have randomly included healthy children of particular age $^{8}$.
Hooman et al., (2004) showed urinary protein/ osmolality ratios in their study and the findings agree well with non-proteinuric group but slightly differ in proteinuric group of the present study. Because they had included all grades of proteinuria in their study but they had not separately described the nephritic range of proteinuria and also the age range was slightly higher ${ }^{19}$.

At the same time the urinary total protein and spot urinary ratio of Group I had also shown strong positive correlation in this study. This study has the similar statistical significance with other studies ${ }^{20}$, 19, 8, 9, 21 . But Hooman et al., (2004) ${ }^{19}$ and Kim et al., (2001) $)^{9}$ in their study had used early morning urine samples and concluded that early morning urine sample can significantly predict the amount of protein excretion by measuring the urinaryprotein osmolality ratio. Morgenstern et al., $(2003)^{8}$ studied with random urine sample and concluded that in children the measurement of protein/creatinine ratios serve the screening purpose better than the protein osmolality ratio to measure urinary protein but in adult both the ratio had equally accurate. David et al., (1993) ${ }^{1}$ in a study compare the protein/osmolality and protein/creatinine ratio with 24 -hour urine protein levels with first morning sample and also random urine sample. They found linear correlation for both the ratio with both sample. The findings of the present study differs from other study in non pathologic proteinuria group of patients, where there was no correlation for both protein/creatinine and protein/osmolality ratios. This might be due to the fact that in the present study samples were collected randomly at any time of the day as per patient convenience. But in other studies the authors used early morning sample for the same purpose.

The spot urinary protein/creatinine ratio and urinary protein/osmolality ratio of Group II in this study did not show any correlation $(r=0.1035$ and 0.0699 ) with urinary total protein. Findings of the present study were in accordance with the findings of Kim et al., (2001) where they also did not find 
any significant correlation with protein/creatinine $(r=0.04)$ or protein/osmolality ratio $(r=0.07)^{9}$.

There were some limitations of this study as this study were conducted in a particular age group, specific timed spot sample were not taken, all group of proteinuric patients were not included, sample size were small, predictive values were not determined and specificity, sensitivity tests were not done.

From all the findings of the present study, it can be concluded that the spot protein/osmolality ratio can be used as a diagnostic tool for the measurement of 24-hour urinary total protein in patients with nephrotic range of proteinuria but not in patients with normal proteinuria.

\section{References}

1. David M. Wilson MD, Ronald LA. Protein/osmolality ratio for quantitative assessment of proteinuria from a random urine sample. Am J Clin Pathol. 1993; 100: 419-24.

2. David VM, Alan MR. The child with abnormal urinalysis, haematuria and/or proteinuria. In: Clinical pediatric nephrology. Webb N, Postlethwaite R (eds), $3^{\text {rd }}$ ed, New York, Oxford University Press, 2003, pp 14-27.

3. Sessoms S, Metha K, Koversky J. Quantitation of protrinuria in SLE by use of a random, spot urine collection. Arthritis Rheum. 1983; 26: 918-20.

4. Abitbol C, Zilleruelo G, Frendlich M, Strauss J. Quantitation of proterinuria with urinary protein/ creatinine ratios with random testing with dipsticks in nephritic children. J Pediatr. 1990; 116: 243-47.

5. Schawab SJ, Christensen L, Dougherty K, Klahr S. Quantitation of protrinuria by use of protein to creatinine ratios in single urine sample. Arch Inter Med. 1987; 147: 943-44.

6. Houser MT. Assessment of proteinuria using random urine samples. J Pediatr. 1984; 104: 845-48.

7. Lemann JJ, Doumas BT. Proteinuria in health and diseases assessed by measuring the Urinary protein/creatinine ratio. Clin Chem. 1987; 33: 297-99.

8. Morgenstern BZ, Butani L, Wollan P, Wilson DM, Laqrson TS. Validity of protein/osmolality versus protein/creatinine ratios in the estimation of quantitative proteinuria from random samples of urine in children. Am J Kidney Dis. 2003; 41: 760-66.

9. Kim SH, Cheon HW, Choe JH, Yoo KH, Hong YS, Lee JW, Kim SK. Quantitation of Proteinuria in children using protein/osmolality ratio. Pediatr Nephrol. 2001; 16: 73-76.

10. Wilson DM, Anderson RL. Protein/osmolality ratio for the quantitative assessment of proteinuria from a random urinalysis sample. Am J Clin Pathol. 1993; 100: 419-24.

11. Hanry RJ. Clinical chemistry: Principle and technique. New York, Harper and Raw, 1964, p 287.

12. Vehaskari VM, Rapola J. Isolated proteinuria: Analysis of a school-age population. J Pediatr. 1982; 101: 66168.

13. Ryland DA, Spreiter S. Prognosis in postural (orthostatic) proteinuria: Forty to fifty-year follow-up of six patients after diagnosis by Thomas Addis. N Engl J Med; 1981; 305: 618-21.

14. Remuzzi G, Bertani T. Is glomerulosclerosis a consequence of altered glomerular permeability to macromolecules? Kidney Int. 1990; 38: 384-94.

15. Kassierr JP, Gennari FJ. Laboratory evaluation of renal function. In: Strauss and Welt's Diseases of the kidney. Early LE, Gottschalk CW (eds). $3^{\text {rd }}$ ed. Boston, Little Brown, 1979, pp 41-91.

16. Rossing P, Hommel E, Smidt UM, Parving H. Impact of arterial blood pressure and albuminuria on the progression of diabetic nephropathy in IDDM patients. Diabetes 1993; 42: 715-19.

17. Shaw AB, Risdon P, Lewis-Jacson J. Protein creatinine index and albustix in assessment of proteinuria. $\mathrm{Br}$ Med J. 1983; 287: 929-32.

18. Houser MT, Jahn MF, Kobayashi A, Walburn J. Assessment of urinary protein excretion in the adolescent: Effect of body position and exercise. J Pediatr. 1986; 109: 556-61.

19. Hooman N, Otukesh H, Safaii H, Mehrazma YS. Quantification of proteinuria with urinary protein to osmolality ratio in children. IJMS. 2004; 29: 168-71.

20. Gyamlani GG, Bergstralh EJ, Slezak JM, Larson TS. Urinary albumin to osmolality ratio predicts 24-hour urine albumin excretion in diabetes mellitus. AJKD. 2003; 42: 455-56.

21. Price CP, Newall RG, Boyd JC. Use of proteincreatinine ratio measurements on random urine samples for prediction of significant proteinuria: A systematic review. Clin Chem. 2005; 51: 1577-86. 